
\section{Ole}

JULY 2020 SPECIAL ISSUE RESEARCH MANUSCRIPT
Nicholas Martinez

University of Florida

Matthew J. Sowcik

University of Florida

James Charles Bunch

University of Florida

\title{
THE IMPACT OF LEADERSHIP EDUCATION AND CO-CURRICULAR INVOLVEMENT ON THE DEVELOPMENT OF SOCIALLY RESPONSIBLE LEADERSHIP OUTCOMES IN UNDERGRADUATE STUDENTS:
}

\section{An Exploratory Study}

\section{Abstract}

Socially responsible leadership (SRL) is a "purposeful, collaborative, values-based process that results in positive social change" (Komives, Wagner, \& Associates, 2009, p. xii).This approach to leadership focuses on creating leaders that are capable of tackling the predicted wicked problems the world will face in the next few decades. As the number of leadership education programs continue to grow throughout higher education, it is important to assess the impact leadership education and co-curricular programs are having on students. Utilizing the MultiInstitutional Study of Leadership, this study aimed to better understand whether higher education leadership development, community service and study abroad programs are successfully developing students with selfperceived socially responsible leadership.

\section{Introduction}

"One thing is certain...the nation's ability to respond and prosper will depend on the quality of leadership demonstrated at all levels of society" (ZimmermanOster \& Burkhardt, 1999). This statement is as true today as it was at the end of last century. Since the 1990s, higher education has embraced the opportunity to transform and develop the current generation of college students into future leaders of tomorrow (Komives, Dugan, Owen, Slack, \& Wagner, 2006; Komives \& Sowcik, 2019). Leadership development is found across most disciplines in higher education and it continues to grow in scope (Komives \& Sowcik, 2019). This diversity in leadership development has led to numerous approaches in the design and delivery of leadership education programs (Jenkins,
2012). The differing approaches to undergraduate leadership education can have a significant impact on the legitimacy of the methods utilized to achieve the leadership education outcomes (Jenkins, 2012). Dugan (2015) posited that while leadership has become a cornerstone of higher education, leadership education needs to be repositioned and reanalyzed.

The Multi-Institutional Study of Leadership (MSL) was created to better "... [understand] the influences of higher education in shaping socially responsible leadership capacity [and] other leadership related outcomes (e.g., efficacy, cognitive skills, resiliency)" (MSL, n.d., para. 1). The MSL research was designed to collect data on undergraduate leadership education in order to understand how different leadership programs and practices affect socially responsible 
leadership (Dugan et al, 2006). Previous research utilizing MSL data has explored the role environmental variables play in the outcomes of student leadership development. In the current study, the researchers examined students' experiences in study abroad and community service during college and how they affected the outcomes of socially responsible leadership. Similar to past research (Luo \& JamiesonDrake, 2014; Astin, Vogelgesang, Ikeda, \& Yee, 2000), the current study found a relationship between students engaging in study abroad, community service and the outcome of socially responsible leadership.

\section{Literature Review}

In the late 1970 s and early 1980s colleges and universities within the U.S. began providing different forms of leadership education (Riggio, Ciulla, and Sorenson, 2003). This change in leadership interest and investment from both large public universities and smaller liberal arts colleges produced a wave of leadership education that began permeating the boundaries of many disciplines across higher education (Riggio et al., 2003; Sowcik \& Komives, 2020). Although the growth of programs was slow at first, by the year 2000 it is suggested there were 800 leadership development programs across the United States (Zimmerman-Oster and Burkhardt, 1999). By the year 2006, nearly 1000 leadership programs existed (Brungardt, Greenleaf, Brungardt, \& Arensdorf, 2006) and according to Guthrie, Teig, and $\mathrm{Hu}$ (2018) there are now over 1,500 undergraduate leadership programs across the country. However, along with this rapid growth has come little consistency to the leadership programs designed, leading to programs that take many different shapes and use a wide array of foundations (Sowcik \& Komives, 2020).

The early study of leadership was often explored utilizing leader-centric models to explain both the practice and education of leaders (Komives,
Lucas, McMahon, 2007). However, over the past three decades, researcher like Komives, Lucas, and McMahon (2007), have expanded on this approach to leadership education by suggesting that, "leadership is a relational and ethical process of people together attempting to accomplish positive change" (p. ix). Perruci (2011) further emphasized the important relationship between followers and leaders, in a defined context, by suggesting leadership is "the process by which leaders and followers develop a relationship and work together toward a goal (or goals) within an environmental context shaped by cultural values and norms" (p. 84).

One particular model of leadership that highlights this relationship between leaders, followers and context is the social change model (SCM) from the Higher Education Research Institute (HERI, 1996). The SCM uses values, called the Seven Cs (Consciousness of self, Congruence, Commitment, Collaboration, Common purpose, Controversy with civility, and Citizenship), to provide leaders with a more holistic focus on the leadership process. Each of the Seven Cs address different parts of the leadership process. For example, Consciousness of self, Congruence, and Commitment are focused on leader values. The values require the leader to be self-aware of all aspects of their leadership, committed to their values, and steadfast in their commitment to their leadership. Collaboration, Common purpose, and Controversy with civility, are all focused on the group relationship the leader has with others. Each of these values reinforce how a leader should focus on others, emphasizing collaborating with all members of the group, creating a common purpose or group identity, and allowing each member of the group to be allowed to share their visions and opinions. Finally, Citizenship emphasizes the dynamics between the leader and their society/community. The value of Citizenship focuses on allowing members of a community to work in collaborative groups to promote positive social change (HERI, 1996). Each of the Seven Cs 
promotes leadership in ways that allow for individuals to be connected to a larger common purpose and create positive social change for their society and community.

Socially responsible leadership (SRL), a form of leadership founded in the tenets of the social change model for leadership development (SCM), seeks to create leaders who embrace a "purposeful, collaborative, values-based process that results in positive social change" (Komives, Wagner, \& Associates, 2009, p. xiii). Socially responsible leadership is often used to define the leadership approach of the SCM. The social change model urges individuals to lead with a common good and to promote social change that positively effects the communities associated with the leadership. Socially responsible leadership demonstrates this type of leadership within the SCM.

While socially responsible leadership (SRL) and the social change model (SCM) are recent approaches to leadership development, higher education institutions have invested heavily in many different types of programs to enhanced leadership and educational effectiveness in their students (Riggio, Ciulla, \& Sorenson, 2003). One type of these educational programs require students to further their studies outside of the classroom and apply it to their personal and professional lives. These experiential learning programs allow students to apply their leadership knowledge and skills to create an environment for feedback and growth (Li, Mobley, \& Kelly, 2012). Two of the more common and influential experiential learning programs in higher education are study abroad and community service involvement. As these programs continue to grow and have an impact on students' leadership development, it becomes increasingly important to better understand how they influence socially responsible leadership outcomes (Dugan \& Komives, 2010).

\section{Community Service}

The impact of community service programs on leadership development have been well documented over the past two decades. Zimmerman-Oster and Burkhardt (1999) identified four hallmarks of an effective leadership development program; context, philosophy, common practices, and sustainability. One of the common practices recommended was community service. Other researchers, like Cress, Astin, Zimmerman-Oster, and Burkhardt (2001) reported "clear evidence of student gains [in involvement] from participation in leadership development programs" (p. 23). Cress et al. (2001) further stated that "opportunities for service" was one of three common elements that emerged from the leadership programs in the study, all having a direct impact on student development (p. 23).

More recently, Lozano (2011) investigated relationships between community service and student outcomes. The findings suggest that students who participated in community service reported, "high levels of ... personal development" (p. 4). Similarly, Smist (2006) found that, "community service, through student organizations or work-study experience, were found to be significant predictors of self-perceived citizenship" (p. 3). Specific to leadership development outcomes Dugan and Komives (2010, p. 528), suggested community service is one of the "relative influence[s] of the college environment on students' leadership development," and there is a positive predictive relationship between leadership capacity and community service. In their study, Dugan and Komives (2010) investigated the influence community service had on socially responsible leadership and found a positive connection to all of the socially responsible leadership outcomes except "Consciousness of self" and "Change".

Study abroad

Known as a foundation of a liberal arts education, higher education institutions are continually developing ways to encourage students to participate in curricular or co-curricular study abroad programs (DiBiasio and Mello, 2014; Green, Luu, \& Burris, 2008). In fact, study abroad programs have continued to grow in the U.S. over the past decade and overall 332,727 students participated in study 
abroad programs in the 2016 - 2017 academic year (IIE, 2018). Although the research on study abroad program outcomes is in its infancy, early research on the topic is reporting links to enhanced personal development, citizenship (Gellhoed, Abe, and Talbot, 2003; Wynveen, Kyle, and Tarrant, 2012; Friar, 2016) and improved intercultural awareness (Gammonley, Rotabi, \& Gamble, 2007). However, while each of these studies point to the benefits associated with the study abroad experiences, very little research addresses the study abroad experiences influence on socially responsible leadership. Although global citizenship, intercultural awareness, increased leadership tendencies, and personal development are all objectives of the Social Change Model (SCM), it is unclear whether they provide students with enough of a foundation to impact their socially responsible leadership levels.

Both community service experiences and study abroad programs have been utilized to advance students' leadership education. However, as previously suggested, not all leadership education programs adhere to the same guidelines or standards. This gap in overall consistency, and at times quality, varies by university, discipline, and department; therefore, it is difficult to measure practices across the field of leadership education (Dugan, Komives, and Owen, 2006). With the creation of the MultiInstitutional Study of Leadership (MSL), leadership education outcomes can be further explored. The purpose of this study is to further understand how leadership education programs and experiential learning programs impact self-perceived levels of socially responsible leadership.

\section{Methods}

\section{Research Design}

This quantitative study is based on cross-sectional survey research design. Visser, Krosnick, and Lavrakas (2000) suggest cross-sectional surveys "involve the collection of data at a single point in time from a sample drawn from a specified population," (p. 225), which is the process the MSL utilizes to procured data. Furthermore, a cross-sectional survey design, using quantitative methods, allows the researcher to produce a "description of trends, attitudes, and opinions of a population" (Creswell \& Creswell, 2018, p. 147).

\section{Purpose}

The purpose of this study was to determine the impact of leadership education and co-curricular involvement on the development of self-perceived levels of socially responsible leadership. Furthermore, the study explored which environmental variable, (a) study abroad, and (b) community service had the most significant variance in a leadership education experience impacting self-perceived levels of socially responsible leadership in undergraduate students.

The following objectives guided this study:

1) Objective 1: Determine if differences occur between leadership education (high-impact leadership education, basic leadership education, and no formal leadership education) and self-perceived socially responsible leadership levels; and

2) Objective 2: Determine if students' environmental variables (study abroad and community service) explain a statistically significant proportion of the variance in their self-perceived socially responsible leadership levels.

\section{Data Collection}

The researchers utilized secondary data collection from the 2015 Multi-Institutional Study of Leadership Student Survey (MSL-SS). The MSL-SS was administered to undergraduate participants from institutions located in the U.S. and internationally from January 2015 to April 2015. All institutions that participated in this study had to enroll in the MSL and were given a guidebook on how to administer the questionnaire, along with consent forms and other supporting documents. The MSL-SS was distributed in an online format that allowed students to take 
the survey at their leisure and convenient to their schedule. The MSL recommended a sample size of at least 4,000 students per institution; however, each institution was allowed to select their own sample size and population. The 2015 MS-SS had 96,588 participants. However, for the first part of the research, addressing the impact of community service and study abroad experiences on self-perceived levels of socially responsible leadership, the researchers only utilized students who were undergraduates, enrolled in U.S. college/university, and were involved in a study abroad and/or community service experience. This provided the researchers with a population of 58,427 participants. Because the sample size was so large, and the researchers' interest in determining the impact of leadership education and co-curricular involvement on the development of self-perceived levels of socially responsible leadership, the population $(\mathrm{N}=58,427)$ was divided into stratum based on shared attributes of leadership education.

The three stratum identified were (a) high-impact leadership education ( $\mathrm{n}=5,841$ ), (b) basic leadership education ( $\mathrm{n}=366$ ), and (c) no formal leadership education ( $n=58,427$ ). The first strata, high-impact leadership education, was populated by those students who had both an experience in a leadership education program (i.e., major, minor, or certificate) and a co-curricular experience (i.e., study abroad and/or community service). The second strata, basic leadership education, were students who only had a leadership education experience (i.e., major, minor, or certificate) but no co-curricular experience (i.e., study abroad and/or community service). The third strata, consisted of students who participated in co-curricular involvement (i.e., study abroad and/or community service), but had no leadership education experience (i.e., major, minor, or certificate). After each stratum was defined, the researchers used a stratified random sample of 300 participants in each stratum. The decision to randomly select 300 participants from each strata provided sample consistency across all stratum since the sample size of each strata varied greatly.

Instrumentation
The instrument used in this research study was the 2015 Multi-Institutional Study of Leadership Student Survey (MSL-SS), which consisted of a 34-item questionnaire that measured leadership development, utilizing the Socially Responsible Leadership Scale (SRLS; Tyree, 1998). The instrument, which measures social change and socially responsible leadership, is dependent on three domains of study: input variables, experiences during college, and outcomes (Tyree, 1998). Dugan (2015) explained that because the MSL-SS has been continuously changed, modified, and tweaked since 2006, the validity of the instrument has been consistent and re-worked to establish psychometric rigor.

\section{Data Analysis}

The data analysis was carried out using SPSS statistics. The first objective used descriptive statistics to first define the subgroups used in this study (high-impact leadership education, basic leadership education, and no leadership education), and then used a oneway analysis of variance (ANOVA) to determine if differences occurred between the subgroups. A posthoc analysis using Tukey HSD was also utilized to further understand where the differences occurred between each of the subgroups. The second objective used a stepwise multiple regression to create a predictive model of the environmental variables (study abroad and community service) and their relationship to socially responsible leadership. If the study abroad or community service involvement explain undergraduate students' levels of socially responsible leadership, then the stepwise regression will determine that the environmental variables explain a statistically significant proportion of the variance in their self-perceived socially responsible leadership levels. This objective was created to identify and understand whether study abroad and/ or community service involvement could benefit the development of socially responsible leadership in leadership in undergraduate students. While this objective did not explicitly state how and what the environmental variables changed or showcased in the students, it was designed to show how the environmental variables are different and could 
produce different socially responsible levels in three subgroups (see Table 1). The findings revealed students.

that high-impact leadership education, the first subgroup, had a mean score of 4.2645 (SD = .52403),

\section{Findings}

The first objective used descriptive statistics to determine the means and standard deviations of the basic leadership education, the second subgroup, had a mean score of 4.0876 (SD = .62744), and no leadership education, the third subgroup, had a mean score of $4.2098(S D=.47335)$.

Table 1.

Socially Responsible Leadership Levels Based on Type of Leadership Education.

\begin{tabular}{cccc}
\hline Variable & $n$ & $m$ & $s d$ \\
\hline $\begin{array}{c}\text { High-Impact } \\
\text { Leadership } \\
\text { Education }\end{array}$ & 300 & 4.2645 & .52403 \\
\hline $\begin{array}{c}\text { Basic Leadership } \\
\text { Education }\end{array}$ & 300 & 4.0876 & .62744 \\
\hline $\begin{array}{c}\text { No Leadership } \\
\text { Education }\end{array}$ & 300 & 4.2098 & .47335 \\
\hline
\end{tabular}

Additionally, a one-way ANOVA was used to determine if differences occur between the three subgroups and levels of socially responsible leadership. Findings showed that there was a statistically significant difference between the groups ( $f=8.271, p=.000$, $\eta 2=0.018$; see Table 2) with a small practical significance (Miles \& Shevlin, 2001). A post hoc test, using Tukey HSD, was used to better understand the differences between each subgroup (see Table 3 ). The findings revealed that participants in the high-impact leadership education subgroup had the highest levels of socially responsible leadership, followed by, and that differences do indeed occur between each subgroup.

Table 2.

ANOVA Summary Table

\begin{tabular}{cc|c|c|c|c|c|c}
\hline $\begin{array}{c}\text { Socially } \\
\text { Responsible } \\
\text { Leadership levels }\end{array}$ & SS & $d f$ & MS & $f$ & Sig. & $\begin{array}{c}\text { Partial } \\
\text { Eta } \\
\text { Squared } \\
\eta^{2}\end{array}$ & $\begin{array}{c}\text { Observe } \\
d \text { Power }\end{array}$ \\
\hline Between Groups & 4.921 & 2 & 2.460 & 8.271 & .000 & .018 & .962 \\
\hline
\end{tabular}

Table 3.

Post Hoc Tests - Multiple Comparisons using Tukey HSD

\begin{tabular}{cc|c|c|c}
\hline \multirow{2}{*}{ Impact Subgroups } & Impact Subgroups & $\begin{array}{c}\text { Mean } \\
\text { Difference }\end{array}$ & Std. Error & Sig. \\
\hline High-Impact & Basic & .17689 & .04453 & .000 \\
\cline { 2 - 5 } Leadership Education & No Lead Ed & .05476 & .04453 & .436 \\
Basic Leadership & High-Impact & -.17689 & .04453 & .000 \\
\cline { 2 - 5 } Education & No Lead Ed & -.12213 & .04453 & .017 \\
No Leadership & High-Impact & -.05476 & .04453 & .436 \\
\cline { 2 - 5 } Education & Basic & .12213 & .04453 & .017
\end{tabular}


The second objective of this study explored the relationship between study abroad, community service experiences, and students' self-perceived socially responsible leadership levels. Using a stepwise multiple regression, it was confirmed that community service is a predicator variable for socially responsible leadership $(\mathrm{R} 2=.053 ; \beta=.231 ; \mathrm{p}=.000$; see Table 4). However, when making decisions, readers should be cautioned because less than $6 \%$ of the variance was explained. When examining study abroad, this predictor variable was found not to be statistically significant in determining self-perceived socially responsible leadership levels. These findings suggest that study abroad experience may not promote higher levels of self-perceived socially responsible leadership. This is in contrast to Lee (2010) who purported that study abroad was not found to be a predictor of student leadership development, it was a small, but statistically significant factor of socially responsible leadership.

Table 4.

Socially Responsible Leadership Levels Based on Type of Leadership Education.

\begin{tabular}{cc|c}
\hline \multicolumn{3}{c}{$(n=300) R^{2}=.053$} \\
\hline $\begin{array}{c}\text { Constant } \\
\begin{array}{c}\text { Service } \\
\text { Participated in Community }\end{array}\end{array}$ & $\beta$ & .231 \\
\hline
\end{tabular}

\section{Discussions, Conclusions, and Recommendations}

This study's findings provided an interesting look into how two experiences that utilize similar foundations shape undergraduate students. Community service, as discussed by Soria et al., (2013), routinely leads to higher levels of socially responsible leadership (SRL). Furthermore, Ricketts, Bruce, and Ewing (2008) discovered that students at a specific land-grant university inside the College of Agricultural Science had a lack of awareness and understanding when trying to serve their community. They suggested that by urging students to join on-campus organizations and take part in serving their community, undergraduate students could have students who are more confident in knowing what their community needs; in turn leading students to have higher levels of socially responsible leadership. Based on the literature and these findings, perhaps community service allows students to engage in the social change model, which then leads to students having higher levels of SRL.
Smist (2006) detailed that community service are experiences that address community needs and can be either curricular or co-curricular. Furthermore, Smist (2006) stated that "[s]tudents involved in community service reported significantly higher citizenship scores than students not involved in community service" (p. 133). Since community service experiences can lead to higher citizenship levels, perhaps this reinforces and explains why students with community service experiences had higher levels of socially responsible leadership. Although Smist (2006) detailed that community service can lead to higher citizenship levels, the other six Cs of the social change model (SCM) were not discussed. This was similarly found in other studies that looked at study abroad experiences and students' levels of citizenship and SRL (see Friar, 2016; Wynveen et al., 2012; Paige, Fry, Stallman, Josić, \& Jon, 2009; Mason \& Their, 2018).

Friar (2016) found that study abroad experiences, regardless of length, had significant increases in global competency and global citizenship development. Friar's (2016) and this study's findings provide an 
interesting account as to why study abroad can promote higher global citizenship (Frair, 2016) and yet fail to produce higher levels of socially responsible leadership. This is intriguing based on the mere fact that citizenship is one of the Seven Cs or values that the social change model (SCM) bases its leadership approach on. This might illustrate that just because one part of the social change model is developed (i.e., Citizenship), an individual will not necessarily have higher levels of socially responsible leadership. Perhaps individuals need to be cultivated or developed in multiple factors of the social change model in order to have a positive impact on their socially responsible leadership levels.

This study's findings also provided an interesting look into how leadership education can promote different outcomes of students based on the level of the education. Objective 1 showcased that high-impact leadership education, leadership education paired with some type of community service and/or study abroad experience, can lead students with higher levels of socially responsible leadership $(M=4.2645$; SD = .52403; Table 1), rather than students who just participate in leadership education $(M=4.0876 ; \mathrm{SD}$ $=.62774 ;$ Table 1) and no leadership education ( $M$ = 4.2098; $\mathrm{SD}=$.47335; Table 1). Interestingly, basic leadership education had the lowest mean score and highest standard deviation of the three subgroups. This, according to this study's findings, suggests that a leadership education (major, minor, or certificate) alone, without co-curricular involvement could lead to lower levels of socially responsible leadership.

The results of Objective 1 support Haber and Komives' (2009) study, which recommended cocurricular pairings with leadership education. The highest SRL mean score was held by the high-impact leadership education group that had students with both a leadership education and either study abroad and/or community service experience. Perhaps this co-curricular pairing allowed students to build a theory base founded in their leadership education and then utilized this information in their co-curricular involvement. This pairing could have allowed students to apply their knowledge during their study abroad or community service and had a larger impression on their SRL levels. Pascarella, Pierson, Wolniak, and Terenzini (2004) suggested that co-curricular involvement provided firstgeneration students with overall academic success. This study and Pascarella et al. (2004) could perhaps solidify Haber and Komives' (2009) findings that cocurricular involvement needs to be implemented into leadership education programs.

Objective 1 also illustrated that a basic leadership education program could lead to lower levels of socially responsible leadership. This could be attributed to the fact that leadership is complex and unknown. Brungardt, Greenleaf, Brungardt, and Arsendorf (2006) studied 15 leadership degree programs and found noticeable differences and inconsistencies between each of the programs. Perhaps due to the lack of a guiding framework or guideline, leadership education lacks the ability to create a uniform program that could result in the lower levels of socially responsible leadership. Another reason for basic leadership education having the lowest levels of socially responsible leadership could be due to the lack of focus leadership education has on creating or promoting good citizenship in students. Smith and Chenoweth (2015) claimed that students who "engaged in co-curricular campus organizations rated themselves on their leadership traits and relational behaviors higher than students who were not involved in these activities" (p. 286). Perhaps cocurricular involvement allows students to engage with their community and utilize service-learning in ways a basic leadership education experience just simply does not allow.

\section{Recommendations for Future Research}

Leadership education programs are vastly different; therefore, more research is needed to further define what constitutes a high-quality leadership education experience. Co-curricular involvement should be further investigated to better understand how these experiences can be paired with leadership education programs. Another recommendation for additional 
research is to determine whether students should prioritize learning of leadership theory before, during or after participating in a co-curricular experience and the impact it has on self-perceived levels of socially responsible leadership. Further research on study abroad and community service experiences is needed, especially exploring the relationships these educational programs have on socially responsible leadership. There are numerous types of community service experiences, research investigating what aspect of community service leads to higher levels of SRL would provide more in-depth analysis as to why community service leads to students with higher levels of self-perceived SRL. Finally, since study abroad experience do not have a uniform approach to delivery, a more in-depth investigation into program components, especially as they relate to student leadership development, is necessary to track how these educational experiences can positively shape undergraduate students' collegiate experiences.

\section{Limitations}

The MSL has primarily focused on the outcomes associated with leadership development programs based on the student's training in leadership (Dugan \& Komives, 2007). Therefore, some of the limitations in this study included the lack of control and tailoring of research survey questions and the inability to determine which leadership programs the students were involved in or which university the students attended at the time of their survey submission. Since the MSL was an ongoing research study, with a defined list of survey questions to determine leadership outcomes, this current study needed to tailor its methods to the survey. This proved to be a limitation, as the researcher was unable to manipulate the survey questions in order to better explore the research problem. Additionally, as the study explored the connections between leadership outcomes and environmental variables, the researcher did not have sufficient data to understand the nature of students' participation in the environmental leadership experiences. For example, the data suggested a student did or did not participate in community service, however, the type of community service was not registered. Finally, it should be noted that this study was exploratory in nature and yielded small practical effects and explained small percentages of variance. As such, this study provided a baseline for future research to be conducted using different types and kinds of designs and analyzes.

\section{Conclusion}

This study aimed to better understand how socially responsible leadership was impacted by leadership education and co-curricular involvement in higher education. Socially responsible leadership is a "purposeful, collaborative, values-based process that results in positive social change" (Komives, Wagner, \& Associates, 2009, p. xii).This approach to leadership focuses on creating leaders that are capable of tackling the predicted wicked problems the world will face in the next few decades (see Sowcik, Andenoro, McNutt, \& Murphy, 2015). Utilizing the MSL allowed researchers to investigate whether higher education leadership development, community service and study abroad programs are successfully developing socially responsible leadership in students. 


\section{References}

Astin, A. W. (1985). Achieving educational excellence: A critical assessment of priorities and practices in higher education. San Francisco, CA: Jossey-Bass.

Astin, A. W. (1991). Assessment for excellence: The philosophy and practice of assessment and evaluation in higher education. New York, NY: American Council on Education.

Brungardt, C. L., Greenleaf, J. L., Brungardt, C. J., \& Arensdorf, J. R. (2006). Majoring in leadership: A review of undergraduate leadership degree programs. The Journal of Leadership Educators, 5(1), 4-24.

Ciulla, J. (2004). Ethics and Leadership Effectiveness. In J. Antonakis, A. T. Cianciolo, \& R. J. Sternberg. The nature of leadership (pp. 302-327). Thousand Oaks, CA: Sage.

Cress, C. M., Astin, H. S., Zimmerman-Oster, K., \& Burkhardt, J. C. (2001). Developmental outcomes of college students' involvement in leadership activities. Journal of College Student Development, 42(1), 15-27.

Creswell, J. W, \& Creswell, J. D. (2018). Research design: Qualitative, quantitative, and mixed methods approaches (5th ed.). Thousand Oaks, CA: SAGE.

DiBiasio, D., \& Mello, N. (2004). Assessing a nontraditional study abroad program in the engineering discipline. Frontiers, 10, 237-252.

Dugan, J. P. (2015). The measurement of socially responsible leadership: Considerations in establishing psychometric rigor. Journal of Educational, Cultural and Psychological Studies, 12, 23-41. Doi: 10.7358/ ecps-2015-012-duga

Dugan, J. P., \& Komives, S. R. (2010). Influences on college students' capacity for socially responsible leadership. Journal of College Student Development, 45, 475-500.

Friar, S. (2016). Global citizenship development: Comparing long-term study abroad, course-embedded study abroad, and non-study abroad students (Doctoral dissertation). Retrieved from ProQuest Dissertations and Theses Global. (Order No. 10158442).

Gammonley, D., Rotabi, K. S., \& Gamble, D. N. (2007). Enhancing global understanding with study abroad: Ethically grounded approaches to international learning. Journal of Teaching in Social Work, 27(3-4), 115-135.

Green, M. F., Luu, D., \& Burris, B. (2008). Mapping internationalization on US Campuses: 2008 Edition. Washington, D.C.: American Council on Education.

Guthrie, K. L., Teig, T. S., \& Hu, P. (2018). Academic leadership programs in the United

States. Tallahassee, FL: Leadership Learning Research Center, Florida State University.

Haber, P., \& Komives, S. R. (2009). Predicting the individual values of the social change model of leadership development: The role of college students' leadership and involvement experiences. Journal of Leadership Education, 7(3), 133-166.

HERI - Higher Education Research Institute. (1996). A social change model of leadership development. College Park, MD: National Clearinghouse for Leadership Programs. 


\section{References}

IIE - Institute of International Education. (2018). Profile of U.S. Study Abroad Student, 2005/06-2016/17. Open Doors report on international exchange. Retrieved from http://www.iie.org/opendoors.

Komives, S. R., Dugan, J. P., Owen, J. E., Slack, C., \& Wagner, W. (2011). Handbook for student leadership programs. San Francisco, CA: Jossey-Bass.

Komives, S. R., Lucas, N., \& McMahon, T. R. (2007). Exploring leadership: For college students who want to make a difference (2nd ed.). San Francisco: Jossey-Bass.

Komives, S. R., Wagner, W., \& Associates. (2009). Leadership for a better world (1st ed.). San Francisco, CA: Jossey-Bass.

Lee, A. M. (2010). Examining the socially responsible leadership development outcomes os study abroad experiences for college seniors (Master's thesis). Retrieved from ProQuest Dissertations and Theses. (Order No. 1482514).

Li, M., Mobley, W. H., and Kelly A. (2013). When do global leaders learn best to develop cultural intelligence? An investigation of the moderating role of experiential learning style. Academy of Management Learning and Education, 12(1), 32-50.

Lozano, R. (2011). The relationship between community service involvement and student outcomes in Mexican higher learning institutions (Doctoral dissertation). Retrieved from ProQuest Dissertations \& Thesis Global; Social Science Premium Collection (Order No. 3482481).

Mason, D. P., \& Their, M. (2017). Study abroad, global citizenship, and the study of nongovernmental organizations. VOLUNTAS: International Journal of Voluntary and Nonprofit Organizations, 29(2), 404-418.

Miles, J., \& Shevlin, M. (2001) Applying regression and correlation: A guide for students and researchers. Sage Publications.

MSL - Multi-Institutional Study of Leadership. (n.d.). Retrieved from https://www.leadershipstudy.net/

Owen, J. E. (2011). Assessment and evaluation. In S. R. Komives, J. P. Dugan, J. E. Owen, W. Wagner, C. Slack, \& Associates, Handbook for student leadership development (pp. 177-202). San Francisco, CA: JosseyBass.

Paige, R. M., Fry, G. W., Stallman, E. M., Josić, J., \& Jon, J. E. (2009). Study abroad for global engagement: The long-term impact of mobility experiences. Intercultural Education, 20(1), S29-S44.

Pascarella, E. T., Pierson, C. T., Wolniak, G. C., \& Terenzini, P. T. (2004). First-generation college students: Additional evidence on college experiences and outcomes. Journal of Higher Education, 75(3), 249-284.

Perruci, G. (2011). Millennials and globalization: The cross-cultural challenge of intragenerational leadership. Journal of Leadership Studies, 5(3), 82-87.

Ricketts, K. G., Bruce, J. A., \& Ewing, J. C. (2008). How today's undergraduate students see themselves as tomorrow's socially responsible leaders. Journal of Leadership Education, 7(1), 24-42. 


\section{References}

Riggio, R. E., Ciulla, J., \& Sorenson, G. (2003). Leadership education at the undergraduate level: A liberal arts approach to leadership development. In S.M Murphy \& R.E. Riggio (Eds.), The future of leadership development. (pp. 223-236). Mahwah, NJ: Lawrence Erlbaum Associates.

Smist, J. A. (2006). Developing citizenship through community service: Examining the relationship between community service involvement and self-perceived citizenship among undergraduates (Master's thesis). Retrieved from ProQuest Dissertations \& Theses Global. (Order No. 1436354).

Smith, L. J., \& Chenoweth, J. D. (2015). The contributions of student organization involvement to students' self-assessments of their leadership traits and relational behaviors. American Journal of Business Education, 8(4), 279-288.

Soria, K., Nobbe, J., \& Fink. (2013). Examining the intersections between undergraduates' engagement in community service and development of socially responsible leadership. Journal of Leadership Education, 12(1), 117-139.

Sowcik, M., Andenoro, A. C., McNutt, M., \& Murphy, S. E. (2015). Leadership 2050: Critical challenges, key contexts, and emerging trends. Bingley, U.K.: Emerald Group Publishing.

Sowcik, M. J. \& Komives, S. R. (2020). How academic programs approach leadership education. New directions for student leadership. Wiley, NY, NYC.

Tyree, T. M. (1998). Designing an instrument to measure socially responsible leadership using the social change model of leadership development (Doctoral dissertation). Retrieved from ProQuest Dissertations and Theses Global. (Order No. 9836493).

Visser, P. S., Krosnick, J. A., \& Lavrakas, P. J. (2000). Survey research. In H. T. Reis \& C. M. Judd (Eds.), Handbook of research methods in social and personality psychology (pp. 223-252). New York, NY, US: Cambridge University Press.

Wynveen, C. J., Kyle, G. T., \& Tarrant, M. A. (2012). Study abroad experiences and global citizenship: Fostering proenvironmental behavior. Journal of Studies in International Education, 6(4), 334-352.

Zimmerman-Oster, K. \& Burkhardt, J. C. (1999). Leadership in the making: A comprehensive examination of the impact of leadership development programs on students. Journal of Leadership \& Organizational Studies, 6(3-4), 50-66. 